\title{
INTENCJE I PRAWDA. UWAGI $O$ WIZJACH POLITYKI QUENTINA SKINNERA
}

Stanisław KNAPOWSKI

Uniwersytet im. Adama Mickiewicza

Quentin Skinner to znany i ceniony historyk brytyjski, szeroko dyskutowany na Zachodzie, mający tam spory oddźwięk w środowisku naukowym oraz tłumaczony na wiele języków. Dla światowej humanistyki już od lat jest postacią niezwykle istotną. W Polsce wciąż pozostaje w dyskursie historyków niemal zupełnie nieobecny, choć w środowisku specjalistów zajmujących się filozofią polityczną zna się go, ceni i cytuje $e^{2}$. Do niedawna, z całego dorobku Skinnera, w języku polskim dostępna była tylko wydana w 2013 roku książka Wolność przed liberalizmem oraz artykuł Znaczenie i rozumienie w historii idei przetłumaczony przez Filipa Białego i opublikowany w czasopiśmie „Refleksje” w 2014 roku, a także kilka innych niewielkich tłumaczeń artykułów lub ich fragmentów. Jednak w 2016 roku pojawiły się dwie niezwykle ważne pozycje. Pierwsza z nich to wydany przez Uniwersytet Mikołaja Kopernika w Toruniu Quentin Skinner. Metoda historyczna i wolność republikańska, zbiór przetłumaczonych artykułów Skinnera, oraz towarzyszących im i korespondujących z nimi, poświęconych Skinnerowi, artykułów polskich autorów. Druga książka to Wizje polityki. Rozważania o metodzie, wydany przez Uniwersytet Kardynała Stefana Wyszyńskiego w Warszawie pierwszy tom wydanych w 2002 Visions of Politics. Zwłaszcza tę książkę uznać można za niezwykle cenną. To pierwsze przetłumaczone na język polski prawdziwe dzieło Skinnera, pierwszy tom jego opus magnum, zbierający w całość porozrzucane wcześniej metodologiczne artykuły i tworzący z nich zwarty korpus myśli.

\footnotetext{
1 Q. Skinner, Wizje polityki, t. 1, Rozważania o metodzie, red. Krzysztof Koehler, Warszawa 2016.

2 J. Grygieńć, „Mniej filozofii, więcej historii”. Quentina Skinnera zmagania z ahistoryzmem w naukach społecznych, „Dialogi Polityczne” 12/2009.
} 
W niniejszym artykule recenzyjnym chciałbym przybliżyć tę ważną dla światowej historiografii postać oraz wyeksplikować najważniejsze myśli i postulaty metodologiczne wylaniające się z Wizji polityki. Skinner jest bowiem historykiem, lecz o bardzo silnych inklinacjach filozoficznych i metodologicznych. Zajmuje się wszak historią myśli politycznej, dziedziną dryfującą pomiędzy historią, filozofią a politologią. Zajmuje w niej ważne stanowisko jako jeden $\mathrm{z}$ wiodących przedstawicieli tak zwanej „Szkoły z Cambridge”. Metodologiczne wskazówki i uwagi Skinnera, jego dosyć surowa i konsekwentna metoda postępowania naukowego może nauczyć historyków z jednej strony rygoryzmu w postępowaniu badawczym, a z drugiej strony pokazuje, gdzie i w jaki sposób pozwolić sobie można, a czasem nawet trzeba, na nieco relatywizmu, na odejście od schematu i poszukiwanie na zupełnie nowych obszarach. Skinner nie jest, przynajmniej obecnie, metodologicznym rewolucjonistą, który chciałby przewracać znów świat na głowę. Jest przede wszystkim historykiem, który zbyt śmiałych filozofów i interpretatorów usiłuje sprowadzić na ziemię. Trzyma się niewzruszenie pewnych zasad i stara się walczyć o to, o czym coraz częściej przedstawicielom humanistyki zdarza się zapominać - o prawdę. Jego nadrzędnym celem jest bowiem poznanie historyczne, obwarowane oczywiście licznymi zastrzeżeniami i wyczulone na liczne delikatne kwestie, jak na przykład lingwistyczny kontekst, jednak ma to być jak najpełniejsze poznanie konkretnej przeszłości.

Twórczość Quentina Skinnera można zasadniczo podzielić na dwa główne nurty. Pierwszy, bardziej historyczny, skupia się wokół myślicieli politycznych wczesnej nowożytności, zwłaszcza z obszaru Włoch i Anglii. I tak zajmował się on Niccolo Machiavellim, Marsyliuszem z Padwy, a także Thomasem Hobbesem, Johnem Locke’em oraz myślicielami republikańskimi doby angielskiej rewolucji. Najważniejszą jego pracą z tej dziedziny jest dwutomowe The Foundations of Modern Political Thought, książka dotąd nieprzetłumaczona na język polski. Drugi nurt skupia się na metodologii historii idei. Jego głównym zagadnieniem są napięcia związane z tekstualizmem $\mathrm{i}$ kontekstualizmem $\mathrm{w}$ interpretacji oraz kwestie lingwistyczne, zaczerpnięte $\mathrm{z}$ dziedzictwa filozofii L. Wittgensteina, J. L. Austina oraz R. Collingwooda. Składają się nań przede wszystkim publikowane w rozmaitych czasopismach artykuły, polemiki i krytyki, a najważniejszą książką tego nurtu są Wizje polityki. Oba rodzaje twórczości Skinner uprawiał równocześnie, wspierając się w badaniach historycznych swoimi metodologicznymi założeniami.

Sądzę, że wykładana w Wizjach polityki metoda Q. Skinnera mogłaby stać się dla historyków cenną inspiracją. Jest ona staranna i wyważona, oparta na tradycyjnym 
brytyjskim myśleniu zdroworozsądkowym, lecz bez popadania w zachowawczy obskurantyzm. Jej zręby zawarł Skinner we wczesnym artykule Znaczenie i rozumienie whistorii idei z $1969 \mathrm{roku}^{3}$. Była ona pracą o tyle odważną, mocno krytyczną i kwestionującą powszechnie ówcześnie panujące w historiografii metodologiczne poglądy ${ }^{4}$. Zasadnicza oś poglądów Skinnera pozostała niezmienna, chociaż wspomniany artykuł przedrukowany w wydanym w 2002 roku pierwszym tomie Visions of Politics: Regarding Method uległ skróceniu i pewnym modyfikacjom to wciąż pozostaje centralnym artykułem, poruszającym najważniejsze wątki tego metodologicznego opus magnum brytyjskiego historyka.

Znaczenie i rozumienie w historii idei to jeden z pierwszych poważnych i znanych artykułów Quentina Skinnera, niemal od razu stał się dla jego późniejszej myśli tak kluczowy i niezwykle ważny. To właśnie nim wybił się w środowisku brytyjskich historyków z własnymi intuicjami i rewolucyjnym podejściem do dotychczasowego traktowania historii idei. Dla książki Wizje polityki stanowi, mimo upływu lat, rozdział centralny, poruszający najważniejsze wątki, który przez pozostałe rozdziały jest tylko uzupełniany i rozwijany. Dlatego uważam, że warto przyjrzeć mu się bliżej i dokładniej, aby na jego podstawie spróbować uchwycić istotę skinneriańskiej myśli metodologicznej.

Już na samym wstępie Skinner dosyć przewrotnie najpierw podaje rekonstrukcji korpus powszechnie uznawanych, stosowanych i cieszących się aprobatą środowiska naukowego założeń dotyczących historii idei, sposobu jej pisania i prowadzenia badań, po czym dokonuje nagłej wolty stanowczo wszystko kwestionując $c^{5}$. Dalsze części tego wyjątkowo długiego artykułu stanowią rozwinięcie i uargumentowanie oskarżeń i zastrzeżeń. Krytykowane przez niego podejście skupia się na badaniu fundamentalnych tekstów klasycznych myślicieli politycznych, w których szuka się odpowiedzi na pewne tematy kanoniczne dla dziedziny filozofii polityki oraz bada uniwersalne idee. Można powiedzieć, że jest to więc krytyka czysto filozoficznego podejścia do badanych tekstów, które w tym ujęciu mają znaczenie tylko wówczas, gdy wypowiadają się na jakiś temat uniwersalny. Skinnera interesuje jednak poznanie i zrozumienie historyczne, tekst ma dla niego sens nie tylko sam dla siebie, lecz także jako pomoc dla zrozumienia jego własnej epoki. Usiłuje dowieść, że dla zrealizowania takich celów praktykowanie poglądów o fundamentalnych i uniwersalnych ideach jest nie tylko obarczone większym ryzykiem błędu, lecz także z gruntu szkodliwe.

\footnotetext{
3 J. Grygieńć, Rekonstrukcja intencji czy dekonstrukcja ideologii?, [w:] Quentin Skinner. Metoda historyczna i wolność republikańska, red. J. Grygieńć, Torun 2016, s. 186.

4 Q. Skinner, Znaczenie i rozumienie w historii idei, [w: ] Q. Skinner, Wizje polityki, Warszawa 2016, s. $95-96$.

5 Tamże, s. 95-96.
} 
Pierwsza część eseju Skinnera to wyliczanie błędnych metodologicznych postaw, a następnie kwestionowanie ich. Najpoważniejszym źródłem tych błędów, przewijającym się przez dalsze części wątkiem, jest ahistoryczne rozumienie dawnych autorów i ocenianie ich za pomocą współczesnych kategorii. Wskutek nietłumionej „mentalnej orientacji obserwatora” nakładamy nieuzasadnione oczekiwania na to, co napisali dawni filozofowie. Przy interpretowaniu, a nawet przy zwykłym czytaniu często implikujemy im nasze własne poglądy i intencje. Oczywiście, nie da się tego wykluczyć w zupełności, nie możemy w pełni uciec od klasyfikowania, jednak nasze oczekiwania odnośnie tego, co ktoś powiedział nie powinny determinować tego co on rzeczywiście napisal, co chcial przez to powiedzieć, i co znaczyło to w jego czasach ${ }^{6}$. Aby jaśniej wyrazić, o co chodzi mu w historii idei i co chciałby osiągnąć, Skinner pokazuje dwa przykłady: z historii sztuki, w której zaczęto badać zmieniające się intencje i konwencje, zamiast samych tylko treści dzieł, oraz z historii nauki, znaną już i docenianą Thomasa Kuhna koncepcję rewolucyjnie zmieniających się paradygmatów. Ten nakreślony horyzont ujawnia aspiracje Skinnera w historii idei. Szuka w pracach historyków nieuświadomionych paradygmatów, które są niemożliwe do zastosowania w przeszłości, i krytykuje, że tworzą oni mitologie zamiast opisów dziejów?

Właśnie mitologiami Skinner nazywa najpoważniejsze metodologiczne błędy, które leżą u podstaw całych naukowych paradygmatów. Jego zdaniem polegają one na nadmiernym skupieniu się na jednym, konkretnym aspekcie badanego tekstu, w skutek czego cel, który na siłę próbujemy osiągnąć, przesłania nam samego badanego autora i jego twórczość. Pierwszą mitologią, z którą Skinner się rozprawia jest tzw. „mitologia doktryn". Polega ona na traktowaniu każdego klasycznego pisarza jakby był odkrywcą własnej doktryny na każdy z tematów uważanych za konstytutywne dla danej dziedzi$\mathrm{ny}^{8}$. Jest to więc nie poszukiwanie prawdy, lecz dopasowywanie wyczytanych treści pod z góry przygotowany schemat, dlatego nie zasługuje na miano prawdziwej historii, lecz właśnie mitologii. Przybiera ona rozmaite formy. Może to być wyszukiwanie $\mathrm{w}$ tekście rozproszonych uwag i następnie przekształcanie ich w doktrynę, która nie została wypowiedziana wprost, lecz imputuje się, że mogła być ona intencją autora. Inne kwestie to konstruowanie sztucznych genealogii intelektualnych, w których bada się tylko następowalność chronologiczną i pewną zbieżność myśli, nie zaś rzeczywisty wpływ jednego pisarza na drugiego. Biografie intelektualne oskarża Skinner o anachronizmy, wyszukiwanie u pisarzy stanowczo zbyt wczesnych doktryn, które pojawiły się znacznie później lecz domniemywa się ich wczesne znamiona już w ich

\footnotetext{
Tamże, s. 97-98.

Tamże , s. 98-99.

8 Tamże, s. 99.
} 
pismach. I tak np. z Marsyliusza z Padwy robi się twórcę pomysłu podziału władz, mimo że raczej nie mógł mieć tego na myśli, a fragment „Obrońcy pokoju”, który mógłby to sugerować jest po prostu powtórzeniem z „Polityki” Arystotelesa ${ }^{9}$. Problem frapujący Skinnera polega na tym, że niektórzy historycy zbyt łatwo dają się zwieść perspektywie odnajdywania w klasycznych tekstach z góry oczekiwanych doktryn, często pochodzących z czasów późniejszych. Odwołanie się do kontekstu danej epoki w prosty sposób dowodzi, że pewne pomysły byłyby w niej nie tyle rewolucyjne, co po prostu niedorzeczne i należy zacząć interpretować je w inny sposób.

Najwięcej krytycznej uwagi Skinner poświęca Arthurowi Lovejoy'owi ${ }^{10}$, historykowi idei, skupionemu właśnie na tym, co najbardziej „zmitologizowane”. Autor ten zajmuje się właśnie „morfologiami” doktryn, śledzeniem historii konkretnych idei na przestrzeni stuleci. Skinner zauważa w tego typu twórczości niebezpieczeństwo stworzenia z doktryny urzeczywistnionej hipostazy, istniejącej już niezależnie od konkretnych myślicieli czy tekstów, nadaniu jej niemalże niezależnego bytu".

Kontrowersyjną kwestią jest ocena moralna dawnych pisarzy. Zbyt często zdarza się, że badacze ganią ich lub chwalą stosując do tego jak najbardziej współczesny standardy, gubiąc z oczu ich historyczną doniosłość i intencje. W gruncie rzeczy sprowadza się to do tego, że, jak przekonuje Skinner, oceniamy filozofów za to, jak bardzo są do nas podobni i czy podzielają nasze poglądy. Dla podania przykładu takiego stanowiska Skinner przywołuje Leo Straussa ${ }^{12}$, który utwory Machiavellego oskarża jako „niemoralne i niereligijne”|3. Niewłaściwa ocena może się wiązać z niezrozumieniem znaczenia kontrowersyjnych treści w okresie, w którym dane dzieło powstawało. Patrząc ze współczesnej perspektywy zbyt łatwo można insynuować myślicielom przekonania na temat współczesnych doktryn, których nigdy nie wyrażali. Najpierw tworzy się pewien model, by następnie wpasować weń konkretnego myśliciela, który rychło staje się obiektem krytyki, gdy jego teksty takiemu działaniu nie zechcą się łatwo podporządkować. Takie praktyki to nic innego jak przypisywanie im swoich własnych uprzedzeń, swoiste „zastawianie pułapek na zmarłych”14. Jest to spostrzeżenie, w którym można doszukiwać się echa poglądów R. Collingwooda, myśliciela, który wywarł znaczny wpływ zarówno na młodego Skinnera, jak i na rozwój całej dziedziny myśli politycznej ${ }^{15}$.

\footnotetext{
9 Tamże, s. 99-101.

10 A. Lovejoy, Wielki łańcuch bytu. Studium historii pewnej idei, Gdańsk 2009.

11 Q. Skinner, Znaczenie i rozumienie w historii idei, dz. cyt., s. 103-104.

12 L. Strauss, Thoughts on Machiavelli, Glencoe 1958.

13 Q. Skinner, Znaczenie i rozumienie w historii idei, dz. cyt., s. 107.

14 Tamże, s. 108-109.

15 F. Biały, Quentin Skinner. Doniosłość i znaczenie, dz. cyt., s. 173.
} 
Skinner przywołuje tematy, które obecnie wydają się interesujące i uznawane są za kluczowe w filozofii polityki. Kluczowe, lecz wcześniej mogły pozostawać nawet zagadnieniami marginalnymi. I tak pytania dotyczące opinii publicznej, zasad głosowania i podejmowania decyzji nabrały znaczenia dopiero wraz z rozwojem nowoczesnych demokracji. Mimo iż próbujemy szukać na nie odpowiedzi u dawnych pisarzy, znaleźć możemy co najwyżej własne uprzedzenia. Platon pomija ten temat, Locke nie uważa za stosowne wyrazić jasnego stanowiska w sprawie wyborów powszechnych ${ }^{16}$, i dla Skinnera jest to całkowicie zrozumiałe. To, o czym pisarze pisali było mniej lub bardziej podporządkowane historycznym warunkom, w jakich żyli, i tematom, które ówcześnie wydawały się ważne. Pisarze nie tylko nie musieli planować napisać tego, czego od nich oczekujemy, ale wręcz niekiedy nie mogli nawet o tym pomyśleć. Tak samo nie mogli przypuszczać, że będą teraz przez nas krytykowani za rzeczy zupełnie im niezrozumiałe.

Następną skinneriańską „mitologią” jest „mitologia koherencji”, która polega na doszukiwaniu się spójności w tekstach, uznanych za nie dość konsekwentne i systematyczne. Stosujący tę metodę oskarżani są o pełne niefrasobliwej dezynwoltury stwierdzenia w stylu: „wytęż wzrok, a spójność sama się znajdzie”, obsesyjne dążenia do zgrabnej egzegezy i ujęcia trudnego i pełnego nieciągłości tekstu w jakieś lapidarne przesłanie $^{17}$. Krytykowane jest tu oczywiście nie samo staranie o dostrzeżenie spójności i konsekwencje w danym tekście, ale o czynienie z niej zasadniczego celu poznania. Skinner ostrzega, że zanikają wówczas rozległe horyzonty interpretacji i ginie nam z oczu niuansowanie myśli, różnorodność podejmowanych przez danego pisarza tematów, szerokość jego zainteresowań ${ }^{18}$. Jeżeli to, co chcemy znaleźć przesłania nam to, co rzeczywiście badamy, to z garści luźnych uwag może nagle urosnąć poważna, lecz misternie zakamuflowana doktryna. Właśnie domniemane zakamuflowanie bywa częstym uzasadnieniem dla nadmiernego skupienia się na wyszukiwaniu spójności za wszelką cenę. Jeżeli bowiem w tekście, po którym oczekujemy koherencji, pojawi się ewentualna niespójność, natychmiast można próbować jakoś ją uzasadnić, nazywając np. sprzecznością pozorną. Jej usprawiedliwieniem jest mocno kontrowersyjna koncepcja „epoki prześladowań”, w czasie której pisarze musieli ukrywać swoje nieortodoksyjne poglądy i zakrywać je, adresując jednocześnie do bardziej inteligentnych czytelników. Zakłada się więc istnienie kluczowych dla zrozumienia dzieła treści ukrytych pomiędzy wierszami. Problem dla takich interpretacji pojawia się jednak wówczas, gdy, nawet w późniejszych wydaniach, nie zmieniają wciąż tych

16 Q. Skinner, Znaczenie i rozumienie w historii idei, dz. cyt., s. 109-110.

17 Tamże, s. 112-113.

18 Tamże, s. 113-114. 
rzekomo zakamuflowanych treści, dlatego w momencie gdy nie mamy absolutnej pewności Skinner proponuje zastosowanie zasady brzytwy Ockhama i stwierdzenie, że pozorna sprzeczność rzeczywiście może być sprzecznościąia

Krytykuje klasyfikowanie pisarzy według jakiegoś modelu, a następnie oczekiwanie, że będą oni do niego aspirować. Wiąże się to według niego z ignorowaniem intencji autorów na rzecz obsesji uspójnienia ich dzieł. Ofiarą tego typu uogólnień padał w brytyjskiej historiografii między innymi Locke, u którego zaciera się różnice między wczesnym a późnym okresem twórczości i przykrywa wspólnym mianem „liberalizmu”, a także Hobbes, któremu insynuuje się, mimo odmiennych deklaracji, intencje pisarstwa religijnie dogmatycznego jako cel całej jego twórczości ${ }^{20}$. Sprzeczności mogą mieć wszak źródło w ewolucji poglądów, a czasem radykalnych woltach intelektualnych danego autora. Jednym z obrońców celowości rozwiązywania sprzeczności w klasycznych tekstach, którego Skinner poddaje szczególnej krytyce jest Leo Strauss ${ }^{21}$, który proponował wyjaśnianie niejasności, czy też nawet „głupstw” domniemaną „erą prześladowań”, w czasie której pisarze musieli ukrywać się ze swoimi poglądami ${ }^{22}$.

Następna i ostatnia, trzecia mitologia określona jest w Znaczeniu i rozumieniu... jako prolepsis, wyprzedzenie. Zgodnie z nią większym zainteresowaniem obdarza się znaczenie myśli danego filozofa współcześnie, czy też w czasach odeń późniejszych niż to, jak była ona rozumiana i jaki miała wpływ w czasach swojego powstania. Skinner zalicza do niej symboliczne stwierdzenia uznające wejście Petrarki na Mont Ventoux za początek renesansu lub oskarżanie Rousseau o położenie filozoficznych podwalin pod totalitaryzm ${ }^{23}$, o to samo oskarżał też Platona Karl Popper ${ }^{24}$, natomiast Leonard T. Hobhouse oskarżał brytyjskich neoheglistów jako winnych bombardowaniom Londynu ${ }^{25}$.

Z punktu widzenia poznania historycznego to błąd, jednak powszechnie powielany nie tylko w historiografii, ale i w filozofii politycznej. Skinner analizuje, jak to zdarza się zupełnie mijać, z tym, co autor rzeczywiście chciał powiedzieć, jeśli szuka się w jego pracach współczesnych, czy klasycznych elementów. W ten sposób, jak dowodzi, Machiavelli sprowadzany jest do roli antycypującego nowoczesność, zaś Locke, to twórca liberalnej szkoly filozofii politycznej - mimo, iż sensu stricte żadnej szkoły ani nie zakładał, ani nie określał się zdecydowanie liberałem. Takie teleologiczne

19 Tamże, s. 117-120.

20 Tamże, s. 115-117.

21 L. Strauss, Persecution and the Art of Writing, Glencoe 1952.

22 Q. Skinner, Znaczenie i rozumienie w historii idei, dz. cyt., s. 119.

23 Ibidem, s. 121-122.

24 K. R. Popper, Społeczeństwo otwarte i jego wrogowie, Warszawa 1993. - moje własne spostrzeżenie.

25 J. Grygieńć, Rekonstrukcja intencji czy dekonstrukcja ideologii?, dz. cyt., s. 187. 
rodzaje wyjaśnień łatwo jest, zdaniem Skinnera, poddać krytyce, gdyż nie trzymają się faktów i nie aspirują do prawdy, lecz jedynie uzasadniają periodyczne i epizodyczne chwiejne dyskursy ${ }^{26}$.

Kolejnym negatywnym obliczem prolepsis są uporczywe starania o wykazanie wpływu jaki miał jeden myśliciel na drugiego. Niekiedy bywają uzasadnione, innym razem wręcz przeciwnie. Skinner wyróżnia trzy, niezwykle rygorystyczne warunki, które powinno spełnić uzasadnienie stwierdzenia wpływu jednego filozofa na konkretną koncepcję innego filozofa. O ile może zachodzić pewne podobieństwo między ich pomysłami, o tyle nie można z niego od razu implikować związku przyczynowo-skutkowego. Niekiedy takie porównania, jak na przykład Hobbesa i Locke'a nie spełniają nawet podstawowego kryterium, czyli pewności, że jeden pisarz czytał drugiego. Kolejne dwa mówiące o tym, że aby wykazać wpływ należy udowodnić, że pisarz A czytał B i daną koncepcję mógł znaleźć tylko w pismach B, oraz, że A nie mógł wymyślić jej samodzielnie, są już niemal nie do spełnienia ${ }^{27}$.

Mówimy o znaczeniu jakiegoś klasycznego dzieła myśli już z perspektywy przewagi czasu, ale przez to nie dostrzegamy pewnych nieoczywistych elementów schowanych w pozornym podobieństwie pod gotowym już spójnym konceptem. Paradoksalnie nakładanie naszej współczesnej, rozleglejszej przecież i głębszej wiedzy filozoficznej, utrudnia nam zrozumienie pewnych działań z przeszłości. „A właśnie jako działania, zgodnie ze swoim austinowskim dziedzictwem filozofii języka ${ }^{28}$, postrzega Skinner polityczne teksty".

Skinner w Wizjach polityki wyraża wiarę we władzę myślicieli nad swoimi intencjami. To oni podpowiadają nam, jak teksty miały być w swoich czasach odczytywane, jakie miały wywołać działanie. Zrealizowanie tego celu badawczego, którym jest de facto sprawozdanie z wypowiedzeń i działań podmiotu, uniemożliwiają obce im klasyfikacje i kryteria ${ }^{29}$. W obliczu tak postawionych przed historią idei zadań wiele podejmowanych przez historyków pytań nie ma w gruncie rzeczy sensu. Nie przybliża nas do zrozumienia istotnego znaczenia badanych klasycznych pisarzy, a czasem prowadzi do absurdów, których kilka przytoczonych jest w artykule w ramach egzemplifikacji. Celem Locke’a nie było przecież antycypowanie metafizyki Berkeleya, jego intencja była zupełnie inna, a nie skierowana na jakichś swoich domniemanych następców. Takie pozbawionego głębszego sensu dywagowanie to, jak określa to Skinner, snucie opowieści, natomiast on sam podnosi bardzo poważną kwestię - że celem narracji

\footnotetext{
26 Q. Skinner, Znaczenie i rozumienie w historii idei, dz. cyt., s. 122-123.

27 Tamże, s. 124-127.

28 J.L. Austin, Jak działamy stowami, [w:] Mówienie i poznawanie. Rozprawy i wykłady filozoficzne, Warszawa 1993.

29 Tamże, s. 129.
} 
historycznej jest śledzenie prawdy. Filozoficzny tekst nie musi być dlań spójną całością, jest bowiem obrazem żywego i trudnego procesu myślenia, którego przejawem są właśnie nieciągłości i sprzeczności, a obrazem pasja włożona w dzieło twórczej myślowej pracy ${ }^{30}$.

Kończąc część polemicznie krytyczną Skinner zaczyna część jawnie i wręcz potępiająco krytyczną, która jednocześnie staje się częścią konstrukcyjną, pełną zarówno budujących metodologicznych uwag, jak i ogólnej wizji tego, jak historia idei powinna wyglądać i jak winno się prowadzić w jej ramach badania. Dowodzi, że wymienione wcześniej kontrowersje to nie tylko drobne metodyczne pułapki, obarczające po prostu pisanie historii większym ryzykiem błędu. Według niego są to przesądy zasadniczo uniemożliwiające właściwe zrozumienie tekstu. Jeżeli bada się to, co pisarz powiedział, natomiast zlekceważy to, co chciał powiedzieć, można dojść do mylących wniosków. Wynika to z rozmaitych czynników utrudniającym nam prawidłowe zrozumienie tekstów dawnych epok. Jedną z większych przeszkód jest zmieniający się język i system podstawowych pojęć słownika społecznego danego okresu. Słowa mogły być przypisane do innych pojęć, a te z kolei być może funkcjonowały już we współczesnym rozumieniu, lecz ujmowane innymi słowami. Skinner przytacza sprawę oceny Georga Berkeleya przez jemu współczesnych, jeżeli padające na jego temat wypowiedzi potraktujemy literalnie, niewątpliwie nie uchwycimy tego, o co naprawdę chodziło. Oskarżając tego filozofa o egoizm nie krytykowano jego aspołecznych zachowań, lecz coś, co dzisiaj określilibyśmy raczej mianem solipsyzmu ${ }^{31}$. Termin ten nie miał bowiem wówczas tak negatywnych jak dzisiaj konotacji. Także słowa samego pisarza bywają zwodniczą wskazówką, jeśli idzie o znaczenie wypowiedzi. Związek między nimi, między wypowiedzią a znaczeniem, może zostać zerwany na przykład przez ironię, ale jej wykrycie to sprawa trudna i wymagająca wiele subtelności i życzliwej próby wczytywania się w intencje autora ${ }^{32}$.

Skinner podnosi ponadto problem rewizjonistycznego badania tekstów, który polega na ich bliskim badaniu, skupianiu się na nich samych w celu najpełniejszego i właściwego ich zrozumienia. Autor Znaczenia i rozumienia... w nawet nieco ironiczny sposób dyskredytuje te rojenia, twierdząc, że czytanie jednego tekstu wciąż „w kółko” w żadnym wypadku nie pomoże nam w rozwiązaniu kontrowersji wokół niego. Jego zdaniem nie jest to przecież zamknięta, skończona i wyabstrahowana od rzeczywistości całość, lecz część znacznie szerszego kontekstu, do którego koniecznie trzeba się odnieść. Badać należy zarówno odbiór społeczny, jak i intencje piszących.

30 Tamże, s. 130-131.

31 Tamże, s. 131-132.

32 Tamże, s. 132-133. 
Dlaczego tak ważne są dla Skinnera właśnie intencje, często przecież kwestionowane w najnowszych teoriach interpretacyjnych? Znów przebija w tym performatywna koncepcja języka zaczerpnięta od J. L. Austina. Celem badacza powinno być uchwycenie nie tylko tego, co ludzie (pisarze) mówią, ale także tego, co robią, kiedy mówią to, co mówią. Skinner nazywa to dwoma zadaniami hermeneutycznymi, z których każde uznaje za nieodzowne do historycznego rozumienia dawnych dzieł.

Wnioskiem, do którego dąży Skinner jest udowodnienie, że tak naprawdę „Nie ma żadnej określonej idei, do której wkład wnieśli różni pisarze, ale (... jedynie wiele wypowiedzi..."33. Dla Skinnera klasyczny tekst polityczny to nie tylko wyrażenie pewnej uniwersalnej prawdy, lecz, może nawet przede wszystkim, określone działanie wymierzone na odniesienie konkretnego skutku i historycznie może być właściwie rozumiane tylko w swojej epoce. „Jedynymi historiami idei do napisania są historie ich użycia w argumentacji”34.

Reasumując: Skinner konkluduje artykuł, wyróżniając wyraźnie dwa pozytywne wnioski: pierwszy dotyczy metody czytania tekstów. Skinner utrzymuje, że aby w pełni i właściwie, w kontekście poznania historycznego, zrozumieć tekst trzeba uznać, iż jest on intencjonalnym aktem komunikacji. Badając, powinniśmy więc pytać, co autorzy pisząc konkretne teksty chcieli zakomunikować swoim odbiorcom, dlaczego pisali w konkretny sposób i jaką reakcję chcieli tym wywołać. Wedle metodologii Skinnera powinniśmy postępować następująco: na początku wyśledzić i wyróżnić wszystkie potencjalne komunikaty, które mogłyby być zawarte w danej wypowiedzi; następnie prześledzić związki między wyrażeniami a „kontekstem lingwistycznym”, czyli językowym tłem, słownikiem, zwłaszcza pojęć społecznych i politycznych, danej epoki i grupy, który stanowi narzędzie pomocne we właściwym, historycznym, odczytywaniu tekstu i intencji pisarza; ostateczną pomocą i poziomem interpretacyjnym, swoistym „sądem apelacyjnym” jest kontekst historyczny analizowanego dzieła myśli ${ }^{35}$.

Wartość studiów z zakresu historii idei widzi Skinner w dialogu pomiędzy filozoficzną analizą z jednej strony, a historycznym materiałem źródłowym, czyli dla prowadzenia narracji - dowodowym. To, czego dokonuje w swoich pracach to zarazem „uhistorycznienie filozofii”, przekształcenie klasycznych dzieł filozoficznych w swego rodzaju źródła, oraz wprowadzenie problematyki filozoficznej do dyskursu historycznego, zwrócenie uwagi na rozwój myśli, historię intelektualną.

Zdaniem Skinnera w historii myśli politycznej naiwnością jest przekraczać kontekst indywidualnych odpowiedzi na indywidualne pytania i konkretnych nacelowanych

33 Tamże, s. 141.

34 Tamże, s. 143.

35 Tamże, s. 143-144. 
na określony skutek działań. Wyraża to wiarę, czy też raczej sceptyczne przekonanie, że studiowanie klasycznych tekstów nie da nam nigdy całościowej odpowiedzi na pytania dotyczące stosunków społecznych. Autor artykułu radzi, byśmy zamiast szukać rozwiązań współczesnych problemów w historii filozofii lepiej myśleli samodzielnie.

Historia idei politycznych w ujęciu Skinnera pokazuje wielość moralnych, politycznych, społecznych pomysłów i rozwiązań, różnorodność przeszłej rzeczywistości, jej powikłanie i przykłady ludzi, próbujących zastany świat uporządkowywać. Wskazuje to na pewnego rodzaju relatywizm, a przynajmniej sceptycyzm aksjologiczny Skinnera. Zakłada on, że nie można być do końca pewnym danego stanowiska i danego rozwiązania. Interpretacje faktów historycznych też mają dla niego znaczenie nie wieczne, lecz lokalne, ograniczone do danych czasów i społeczeństwa, które próbuje na swój sposób zrozumieć proces dziejowy.

Z historii idei możemy wyciągnąć co najwyżej wiedzę, że nie istnieje jedno ponadczasowe pojęcie, uniwersalna idea, a tylko wielość różnorodnych pojęć odpowiednich swoim czasom i społeczeństwom, w których były używane. Historia, zdaniem Quentina Skinnera, może dać nam lekcje samowiedzy - zrozumienia własnego społeczeństwa, języka, ograniczeń poprzez analogie z historycznymi badaniami ograniczeń innych, wcześniejszych społeczeństw ${ }^{36}$.

\section{BIBLIOGRAFIA}

Austin J. L., Jak działamy stowami [w: ] Mówienie i poznawanie. Rozprawy i wykłady filozoficzne, przeł. Bohdan Chwedeńczuk, Warszawa 1993.

Biały F., Quentin Skinner. Doniostość i znaczenie [w:] „Refleksje” nr 9 (2014).

Grygieńć J., „Mniej filozofii, więcej historii”. Quentina Skinnera zmagania z ahistoryzmem w naukach społecznych, „Dialogi Polityczne” 12/2009.

Grygieńć J., Rekonstrukcja intencji czy dekonstrukcja ideologii? [w:] Quentin Skinner. Metoda historyczna i wolność republikańska, red. J. Grygieńć, Toruń 2016.

Lovejoy A., Wielki łańcuch bytu. Studium historii pewnej idei, Gdańsk 2009.

Popper K.R., Społeczeństwo otwarte i jego wrogowie, Warszawa 1993.

Skinner Q. Moralność renesansowa a sztuka krasomówstwa, przeł. K. Wawrzonkowski [w:]

Quentin Skinner: metoda historyczna i wolność republikańska, red. J. Grygieńć, Toruń 2016. Skinner Q. Znaczenie i rozumienie w historii idei [w: ] Q. Skinner, Wizje polityki, przel. K. Koehler,

K. Koehler, Warszawa 2016.

Strauss L., Persecution and the Art of Writing, Glencoe 1952.

Strauss L., Thoughts on Machiavelli, Glencoe 1958.

36 Tamże, s. 146. 